\title{
Isolation and Characterization of the Facultative Methylotroph Mycobacterium ID-Y
}

\author{
By WILLIAM M. REED† AND PATRICK R. DUGAN* \\ Department of Microbiology. The Ohio State University, Columbus, Ohio 43210, USA
}

(Received 23 May 1986; revised 14 November 1986)

A facultatively methylotrophic Mycobacterium was isolated from Cleveland Harbor, Ohio, USA. The isolate, designated ID-Y, used a wide range of carbon and energy sources including methane and several other hydrocarbons. It displayed a growth cycle from rod-shaped exponential-phase cells, with many cell pairs exhibiting $V$-formation, to cocco-bacillary stationary-phase cells. A fixation technique involving glutaraldehyde/alcian blue resulted in the observation of a three-layered cell wall. Isolate ID-Y has an ultrastructure similar to that of other mycobacteria, particularly Mycobacterium phlei and Mycobacterium flavum, which is presently classified as a Xanthobacter species.

\section{INTRODUCTION}

Two major groups of methane-oxidizing bacteria are recognized, obligate and facultative. Obligate methane-oxidizing bacteria are strictly aerobic, Gram-negative rods, vibrios or cocci which use only $\mathrm{C}_{1}$ compounds or multiple carbon compounds with no carbon-to-carbon bonds. The majority of the facultative methane-oxidizing bacteria have similar characteristics and also the ability to utilize organic compounds with more than one carbon atom and carbon-to-carbon bonds. The methane-oxidizing mycobacteria have been studied infrequently, possibly due to the difficulty of isolation of these organisms in pure culture; they do not appear to fit the general description of the majority of facultative methylotrophs. This report describes a facultatively methylotrophic Mycobacterium that has a three-layered cell wall and displays characteristics similar but not identical to the organism originally described by Nechaeva (1949), and provides an isolate for further study of a facultative methylotroph thought to be no longer in existence.

\section{METHODS}

Isolation and maintenance of cultures. Enrichment cultures of methylotrophic bacteria were obtained by inoculating $5 \mathrm{ml}$ Lake Erie water into a rubber-stoppered $74 \mathrm{ml}$ serum bottle containing $35 \mathrm{ml}$ sterile CM mineral salts medium (CM; Weaver \& Dugan, 1975). Before inoculation, $10 \mathrm{ml}$ air was withdrawn from and $10 \mathrm{ml}$ sterile $\mathrm{CH}_{4}$ injected into each of the stoppered serum bottles. After inoculation, the enrichment cultures were incubated statically for $48 \mathrm{~h}$ at $30^{\circ} \mathrm{C}$. Samples from the enrichment cultures were then streaked onto $\mathrm{CM}$ agar and incubated in a desiccator under $\mathrm{CH}_{4} /$ air $(1: 1, \mathrm{v} / \mathrm{v})$ at $30^{\circ} \mathrm{C}$. After several transfers on $\mathrm{CM}$ agar under $\mathrm{CH}_{4} /$ air, one of four isolates, designated ID-Y, was capable of growth on trypticase soy agar (TSA, BBL). ID-Y was repeatedly transferred from TSA plates to $\mathrm{CM}$ agar plates under $\mathrm{CH}_{4}$ /air and from $\mathrm{CM}$ plates back to TSA plates. A colony was diluted in liquid $C M$ medium and the greatest dilution demonstrating growth was streaked onto mineral salts agar and incubated under $\mathrm{CH}_{4} /$ air $(1: 1, \mathrm{v} / \mathrm{v})$.

Liquid cultures were maintained in rubber-stoppered $125 \mathrm{ml}$ Erlenmeyer flasks containing $25 \mathrm{ml} \mathrm{CM}$ medium. Before inoculation the rubber stopper of each flask was swabbed with an acetone-saturated piece of cotton. Culture fluid was injected through the rubber stopper with a sterile syringe. After inoculation, the flask was purged with glasswool-filtered $\mathrm{CH}_{4} /$ air $(1: 1, \mathrm{v} / \mathrm{v})$. The bottles were agitated on a rotary shaker at 95 r.p.m. Cultures were also maintained on $\mathrm{CM}$ agar plates in a glass desiccator filled with $\mathrm{CH}_{4} /$ air $(1: 1, \mathrm{v} / \mathrm{v})$. The desiccators were

† Present address: CPC International, Moffett Technical Center, Box 345, Argo, IL 60501, USA. 
swabbed with acetone before each weekly culture transfer to combat contamination with fungi. The purity of the $\mathrm{CH}_{4}$ was $99 \cdot 1 \%$.

Growth studies. The ability of ID-Y to grow on numerous substrates as sole carbon and energy sources was investigated. $\mathrm{CM}$ agar plates containing $0.5 \%(\mathrm{w} / \mathrm{v})$ lignin sulphonate [Maracell $\mathrm{E}$, Marasperse CB, (American Can Co.), Indulin C or Polyfon O, (Westvaco)] or $1 \%(\mathrm{w} / \mathrm{v})$ glucose or nutrient agar (Difco) were inoculated, incubated for 2 weeks at $21{ }^{\circ} \mathrm{C}$, and observed for growth. Liquid cultures of $\mathrm{CM}$ medium containing $1 \%$ glucose, $0.2 \%$ succinate, $0.1 \%$ methanol, $0.1 \%$ ethanol, $0.1 \%$ hexane or $0.1 \%$ hexadecane were incubated at $21{ }^{\circ} \mathrm{C}$ on a rotary shaker (160 r.p.m.) and observed for growth after 2 weeks. Flasks containing CM medium and ID-Y were incubated similarly, under an atmosphere of air plus methane, ethane, propane or butane $(1: 1, \mathrm{v} / \mathrm{v})$ and observed for growth after 2 weeks. Four-day liquid cultures (early stationary) of ID-Y grown on $\mathrm{CH}_{4}$ were used as inocula for growth studies. The initial cell density for all growth studies in liquid culture was $6 \times 10^{7} \mathrm{cells} \mathrm{ml}^{-1}$. Ion Agar no. 2 (Oxoid) at a concentration of $0.9 \%(w / v)$ was used in all agar plates. Carbon sources were autoclaved or filtersterilized separately and added to the growth medium.

Gas analysis. Methane was analysed with a Varian 2740 series gas chromatograph equipped with a $183 \times$ $0.32 \mathrm{~cm}$ steel column packed with Porapak $Q$ and a flame ionization detector. The carrier gas was prepurified $\mathrm{N}_{2}$ with a flow rate of $20 \mathrm{ml} \mathrm{min}-1$. Temperatures of $105^{\circ} \mathrm{C}$ for the column and $175^{\circ} \mathrm{C}$ for the injector and detector were maintained. Gas samples were collected from the headspace of culture serum bottles with a Pressure-Lok $100 \mu \mathrm{l}$ gas syringe. Sterile serum bottle controls were analysed to account for adsorption of $\mathrm{CH}_{4}$ by the bottle or loss via diffusion through the butyl rubber stoppers.

Isolation of DNA and buoyant density determination. Cells were disrupted by liquid nitrogen cryo-impacting (Smucker \& Pfister, 1975). The disintegrated cell mass was held at $-20^{\circ} \mathrm{C}$ until needed. DNA was extracted using a method adapted from Marmur (1961) and Bolivar \& Backman (1979). Crude Escherichia coli lysates (courtesy of William F. Martin, Ohio State University) were similarly extracted, purified and used for comparison. The DNA was analysed by $\mathrm{CsCl}$ density gradient centrifugation with an adaptation of the methods of Schildkraut $e t$ al. (1968). Solution density was determined from the refractive index (Weast, 1979). The guanine plus cytosine content was calculated from the buoyant density using the relationships published by Schildkraut et al. (1962). E. coli DNA was used as an internal marker.

Electron microscopy. Specimens were prepared for thin sectioning by fixation for $5 \mathrm{~h}$ at $21{ }^{\circ} \mathrm{C}$ in a glutaraldehyde/ alcian blue solution as employed by Benke \& Zelander (1970): $16 \mathrm{ml} 25 \%(\mathrm{v} / \mathrm{v})$ glutaraldehyde and $7 \mathrm{~g}$ alcian blue were dissolved in veronal/acetate buffer (Kellenberger $e t$ al., 1958) to make $100 \mathrm{ml}$. The sample was washed twice with distilled $\mathrm{H}_{2} \mathrm{O}$ and post-fixed in $2 \%(\mathrm{w} / \mathrm{v}) \mathrm{OsO}_{4}$ in veronal/acetate buffer overnight at $4{ }^{\circ} \mathrm{C}$. The sample was washed twice in veronal/acetate buffer. Post-fixation in $2 \%(w / v)$ uranyl acetate was carried out for $2 \mathrm{~h}$ at $21{ }^{\circ} \mathrm{C}$. The cells were washed in veronal/acetate buffer and resuspended in $2 \%$ agar. Small blocks of the agar were rinsed with $50 \%(\mathrm{v} / \mathrm{v})$ acetone and immersed in $2 \%$ uranyl acetate in $10 \%$ acetone for $15 \mathrm{~min}$. The blocks were dehydrated and embedded in Spurr's low viscosity embedding medium (Spurr, 1969). Thin sections were cut with a diamond knife on an LKB model III ultramicrotome. Sections were post-stained with both uranyl acetate and lead citrate. Cells were prepared for freeze etching by the procedure of Steere (1957). A Philips EM-300 was used to examine all specimens. Exponential-phase cells were used for electron microscopy except where otherwise indicated.

\section{RESULTS AND DISCUSSION}

ID-Y cells were non-motile, Gram-positive, acid-fast rods identified as a Mycobacterium. Colonies on semi-solid growth media were smooth, raised, entire, and yellow pigmented. Biochemical tests with cells grown on either $\mathrm{CM}$ medium under $\mathrm{CH}_{4} /$ air or trypticase soy broth indicated that the cells are catalase and oxidase positive and reduced nitrate to nitrite. Negative results were recorded for phenylalanine deamination, $\mathrm{H}_{2} \mathrm{~S}$ production, motility, indole production, methyl red/Voges-Proskauer reactions, gelatin hydrolysis, starch hydrolysis and skim milk alteration. No acid or gas was produced from arabinose, dulcitol, galactose, glucose, lactose, maltose, mannose, rhamnose, sorbitol, sucrose, trehalose or xylose.

DNA of the cryoimpacted ID-Y cell preparation yielded about $400 \mu \mathrm{g}$ per $\mathrm{g}$ bacteria (wet weight) and had a density of $1.727 \mathrm{~g} \mathrm{~cm}^{-3}$, which corresponds to a guanine plus cytosine content of $68 \mathrm{~mol} \%$. The DNA from ID-Y grown on methane had the same density as that from cells grown on glucose, which supports the conclusion that the isolate is a single strain and not a mixture of two different micro-organisms.

After $14 \mathrm{~d}$ ID-Y formed colonies of $1 \mathrm{~mm}$ diameter on $\mathrm{CM}$ agar under $\mathrm{CH}_{4} /$ air and of 1 to $1.2 \mathrm{~mm}$ diameter on $1 \%$ glucose $/ \mathrm{CM}$ agar. The isolate grew poorly on nutrient broth agar, producing pinpoint colonies after $10 \mathrm{~d}$, but grew well in nutrient broth. 
ID-Y grew over a temperature range from 15 to $42^{\circ} \mathrm{C}$, with an optimum range from 28 to $35^{\circ} \mathrm{C}$. At temperatures above $31^{\circ} \mathrm{C}$ opaque colonies with little or no pigment were produced. However, when plates containing these opaque colonies were transferred to $28^{\circ} \mathrm{C}$ the yellow pigment appeared within $2 \mathrm{~h}$. The pigment was completely extractable with ethanol and was the same in the presence or absence of light.

ID-Y was capable of growth on many substrates including compounds as complex as ligninsulphonates (CM agar plates containing $0.5 \%$ Maracell $\mathrm{E}$, Marasperse $\mathrm{CB}$, Indulin $\mathrm{C}$ or Polyfon $\mathrm{O}$ ). Growth was also observed on glucose, propane, butane, hexane, hexadecane and methane but not on ethane, ethanol, methanol or succinate. A generation time of $25.7 \mathrm{~h}$ on $\mathrm{CH}_{4}$ and $10.3 \mathrm{~h}$ on $0.05 \%$ yeast extract was determined for ID-Y at $21{ }^{\circ} \mathrm{C}$.

ID-Y grew as rods of 1.3 to $2.6 \mu \mathrm{m} \times 0.2$ to $0.3 \mu \mathrm{m}$ in $24 \mathrm{~h}$ nutrient broth cultures during exponential phase but the cells were cocco-bacillary $(0.4$ to $0.8 \mu \mathrm{m}$ diameter $)$ during stationary phase. In either glucose or $\mathrm{CH}_{4}$ cultures, the cells in stationary phase were shorter than those of exponentially growing cells. The organism displayed V-forms in most exponential and some stationary cultures. When grown in hexadecane/CM medium most of the cells partitioned into the oil droplets. Although ID-Y appears to be similar to the methylotrophic Mycobacterium spp. originally described by Nechaeva (1949) and Seto et al. (1975), which are no longer available, it differs from Mycobacterium cuneatum in its ability to grow on hexane. M. cuneatum grew on ethane, ethanol and methanol whereas ID-Y did not. ID-Y had a guanine plus cytosine content of $68 \mathrm{~mol} \%$ as compared to $64.9 \mathrm{~mol} \%$ and $66.3 \mathrm{~mol} \%$ for two strains of $M$. cuneatum. ID-Y differs from $M$. flavum var. methanicum and Mycobacterium methanicum (Nechaeva, 1949) in its ability to reduce nitrate and hydrolyse starch. ID-Y also has traits similar to descriptions of Mycobacterium gordonae (Park \& DeCiccio, 1974) and to Xanthobacter flavus, a species which includes some isolates previously classified as Mycobacterium flavum (Wiegel \& Schlegel, 1984).

The effect of increasing concentrations of yeast extract on $\mathrm{CH}_{4}$ consumption is shown in Fig. 1. Supplementation with $0.001 \%$ yeast extract resulted in an initial stimulation of $\mathrm{CH}_{4}$ consumption which probably reflects an increase in cell density due to addition of growth factors. After $2 \mathrm{~d}$, consumption of $\mathrm{CH}_{4}$ ceased. When the concentration of yeast extract was raised to $0.01 \%$, consumption of $\mathrm{CH}_{4}$ again ceased after $2 \mathrm{~d}$ following a less dramatic period of stimulation, which suggests that the cells switch to yeast extract as their source of carbon and energy.

Although it was difficult to obtain satisfactory negative strains of ID-Y, probably due to the hydrophobic nature of its surface, Fig. 2 shows internal granules which were occasionally observed at each end of cells grown on many different substrates and always in $\mathrm{CH}_{4}$-grown cells. Also evident was the outer periphery of the cell wall which looked like a light shadow outside the cell. Pairs of cells were frequently arranged in the characteristic V-formation as shown in Fig. 2 and described for other mycobacteria (Edwards, 1970; Hirata, 1979; Imaeda \& Ogura, 1963; Petitprez et al., 1967) and Arthrobacter species (Kolenbrander \& Hohman, 1977).

Fixation of cells using the technique of Kellenberger et al. (1958) resulted in poor elucidation of the cell wall with badly condensed DNA. However, when a fixation technique using glutaraldehyde/alcian blue was substituted (Benke \& Zelander, 1970), the cells displayed fibrillar DNA, a plasma membrane, and a cell wall (Fig. 3). The cytoplasmic membrane showed three layers with the external layer appearing much more electron dense. A periplasmic space was also observed. The three layers of the cell wall had diameters of: $6 \mathrm{~nm}$, inner wall components; $17 \mathrm{~nm}$, middle wall components; $6 \mathrm{~nm}$, outer wall components. This envelope is very similar to those of other mycobacteria as described by Petitprez et al. (1967) and Imaeda et al. (1968).

Fig. 4 shows a cell from a glucose exponential-phase culture which has completed septum formation. The septum is composed of four components : a plasma membrane and an inner cell wall component on either side of a transparent zone which had an average diameter of $27 \mathrm{~nm}$. The width of the septum was $21 \mathrm{~nm}$ at each end and $30 \mathrm{~nm}$ at the centre. A mesosome is in close association with the septum. Throughout division, ID-Y cells were cuneate with a distinct taper from the septal to distal ends. Cells from exponential-phase nutrient broth cultures were morphologically and ultrastructurally similar to glucose- and $\mathrm{CH}_{4}$-grown cells. However, cells 


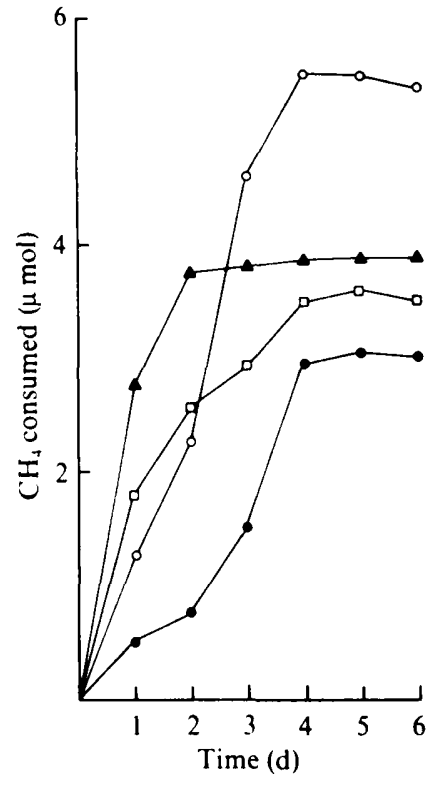

Fig. 1

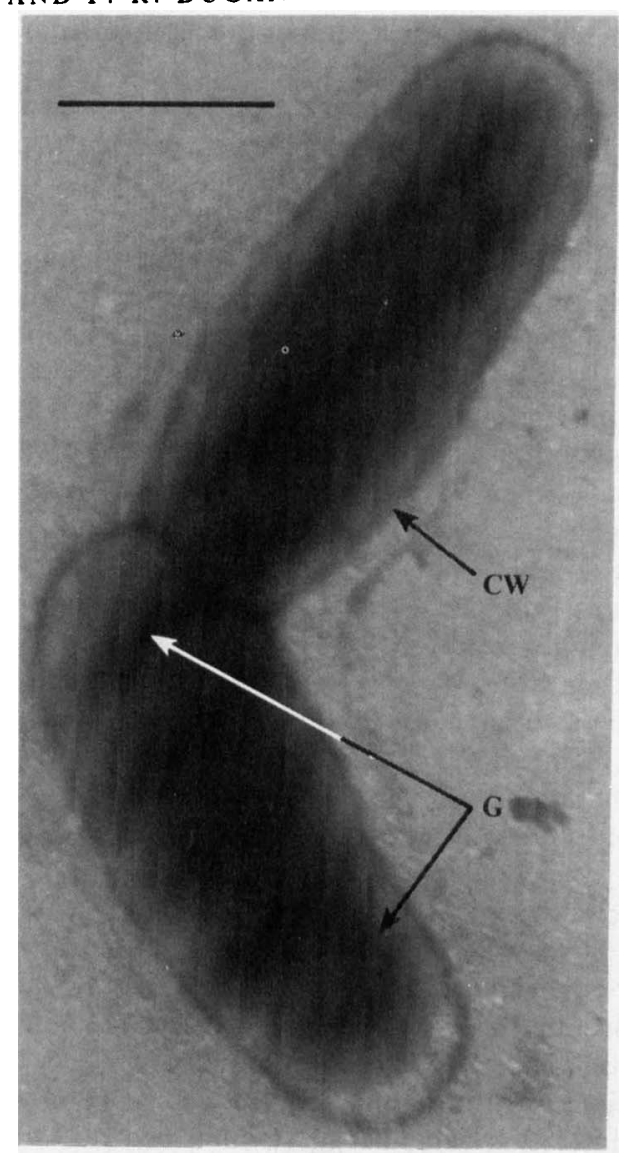

Fig. 2

Fig. 1. Consumption of $\mathrm{CH}_{4}$ by ID-Y grown in $\mathrm{CM}$ medium without yeast extract $(\mathrm{O})$ and in $\mathrm{CM}$ medium plus $0.01 \%(\square)$ or $0.001 \%(\Delta)$ yeast extract. $\bigcirc$, Control (sterile $\mathrm{CM}$ medium).

Fig. 2. Electron micrograph of two ID-Y cells in a V-formation. The cells were taken from a $1 \mathrm{~d}$ culture on $\mathrm{CH}_{4}$ and negatively stained with $1 \%$ uranyl acetate. The internal granules $(\mathrm{G})$ were sometimes observed in cells grown on other substrates and always in $\mathrm{CH}_{4}$-grown cells at each end of the cell. Also evident is the outer periphery of the cell $(\mathrm{CW})$ which looks like a capsule. Bar, $0.4 \mu \mathrm{m}$.

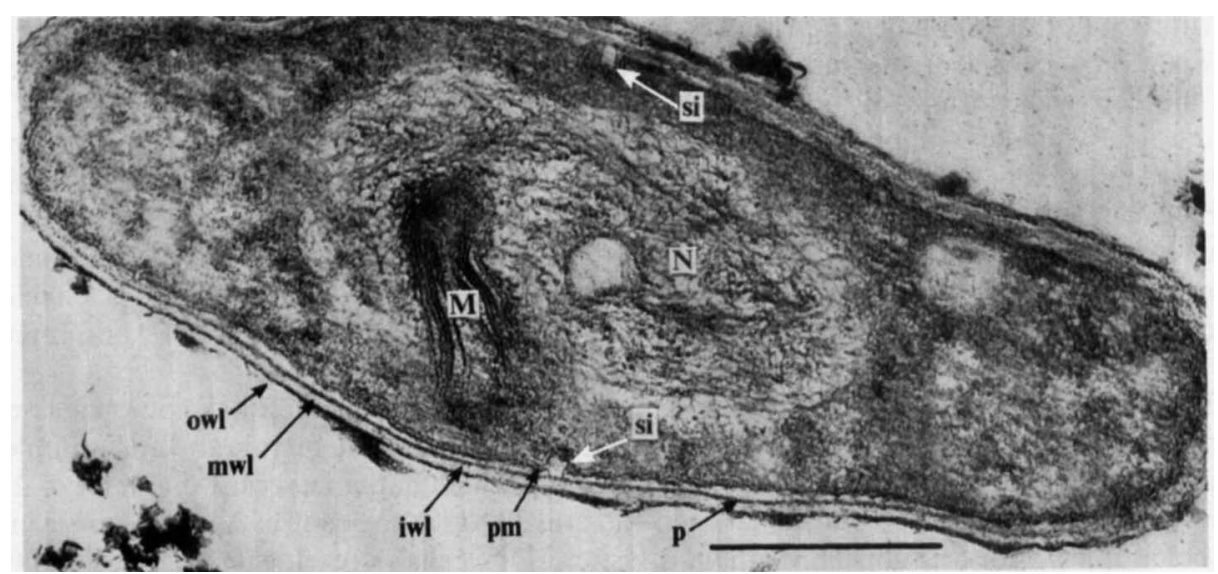

Fig. 3. Thin sections of ID-Y grown on glucose for $1 \mathrm{~d}$ and fixed with glutaraldehyde/alcian blue. iwl, Inner wall layer; $M$, mesosome; mwl, middle wall layer; $N$, nuclear material; $P$, periplasmic space; $p m$, plasma membrane; owl, outer wall layer; si, septum initiation. Bar, $0.4 \mu \mathrm{m}$. 


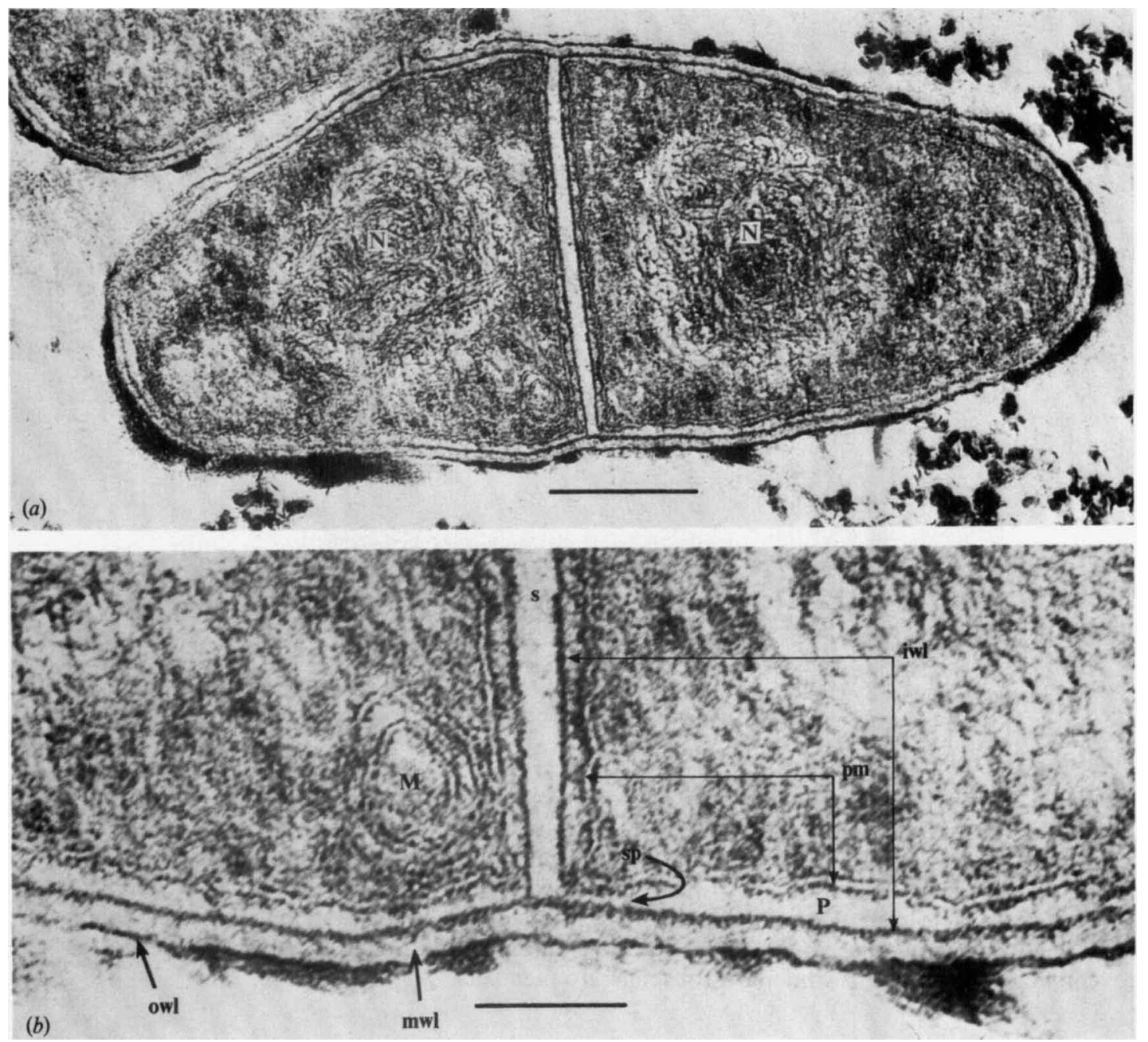

Fig. 4. ID-Y grown in glucose for $1 \mathrm{~d}$ and fixed with glutaraldehyde/alcian blue. $(a)$ Cell in which septum formation is complete. (b) Enlargement of septum. iwl, Inner wall layer; $\mathbf{M}$, mesosome; mwl, middle wall layer: $N$, nuclear material; $P$, periplasmic space; $\mathrm{pm}$, plasma membrane; owl, outer wall layer; s, septum; sp, space. Bars, $0.4 \mu \mathrm{m}(a), 0 \cdot 1 \mu \mathrm{m}(b)$.

from late stationary $(21 \mathrm{~d})$ nutrient broth cultures had a cocco-bacillary shape and displayed a thicker $8.5 \mathrm{~nm}$ inner wall component layer and an electron-dense material which was associated with the plasma membrane and in most cells filled the periplasmic space and extended into vesicular mesosomes which were characteristic of these cells (Fig. 5). Similar vesicular mesosomes have been observed in Mycobacterium lepraemurium and a Mycobacterium sp. (Imaeda \& Ogura, 1963) and in Bacillus subtilis (Van Iterson, 1961). The intracytoplasmic membrane system characteristic of obligate (Whittenbury et al., 1970) and some facultative methane-oxidizing bacteria (Patt \& Hanson, 1978) were absent in ID-Y. It may be that in ID-Y the mesosomes perform the function of the intracytoplasmic membrane systems of other methane-oxidizing bacteria.

Satisfactory freeze-etch preparations of ID-Y were difficult to obtain. Most of the cells did not cleave and organic material could not be completely removed from replicas. However, surface fibrils and rings were observed in freeze-etch preparations. Imaeda et al. (1968) reported that fibrils on the surface of young cells showed an irregular arrangement and sometimes twisted 


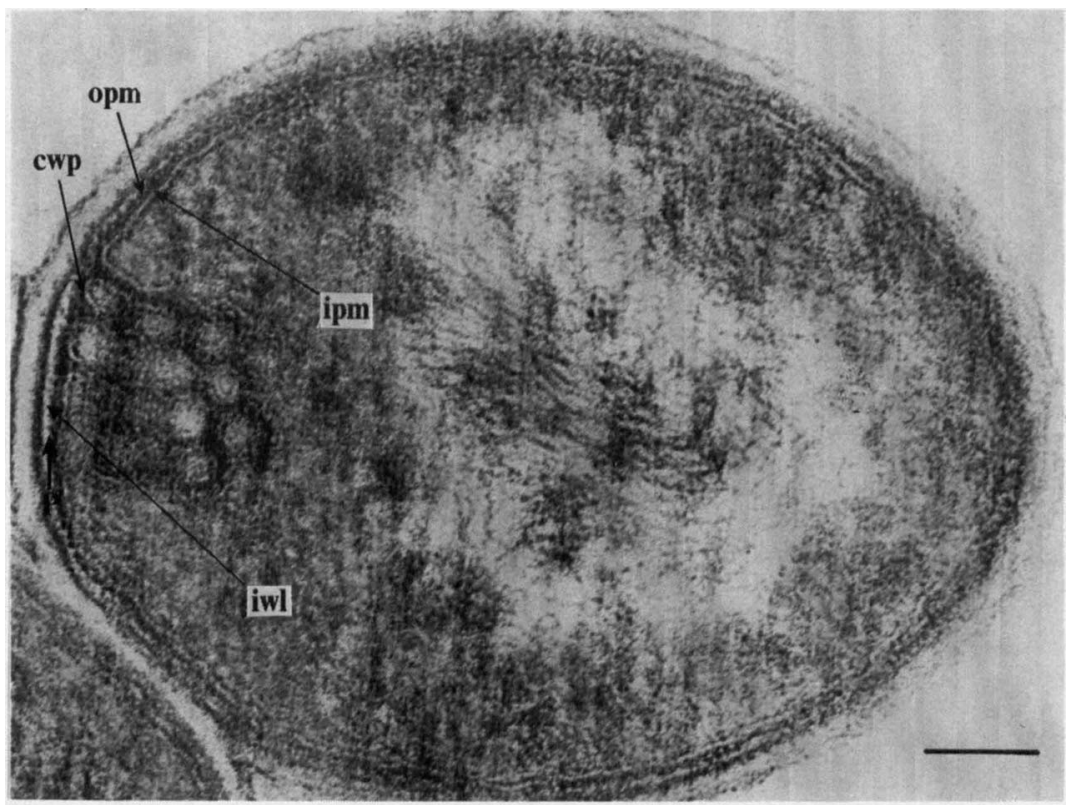

Fig. 5. ID-Y cells from a $21 \mathrm{~d}$ stationary phase culture grown in nutrient broth. cwp, Dense material associated with the outer layer of the plasma membrane; ipm, inner layer of the plasma membrane; iwl, inner cell wall layer; opm, outer layer of the plasma membrane; $P$, periplasmic space. Bar, $0 \cdot 1 \mu \mathrm{m}$.

taking a 'spun yarn' form, while older cells displayed few fibrils which frequently ran parallel. Surface rings not previously reported on mycobacteria but similar to those observed on Arthrobacter crystallopoietes (Kolenbrander \& Hohman, 1977) are present in young and old cells. With each cell division a new ring formed on each sister cell. The presence of surface rings, the growth cycle from rod-shaped exponential-phase cells to coccoid stationary cells, and the Vformation displayed by many cell pairs reflects a morphological similarity between ID-Y and the coryneform bacteria of which arthrobacters are members.

\section{REFERENCES}

Benke, O. \& Zelander, T. (1970). Preservation of intracellular substances by the cationic dye alcian blue in preparative procedures for electron microscopy. Journal of Ultrastructure Research 31, 424-430.

Bolivar, F. \& Backman, K. (1979). Plasmids of Escherichia coli as cloning vectors. Methods in Enzymology 68, 245-267.

EDWARDS, R. P. (1970). Electron-microscope illustrations of divisions in Mycobacterium leprae. Journal of Medical Microbiology 3, 493-499.

HiRata, T. (1979). Electron microscopic observations of intracytoplasmic membrane systems and cell division in Mycobacterium lepraemurium. International Journal of Leprosy 47, 585-596.

IMAEDA, T. \& OGURA, M. (1963). Formation of intracytoplasmic membrane system of mycobacteria related to cell division. Journal of Bacteriology 85, 150-163.

Imaeda, T., Kanetsuna, F. \& Galindo, B. (1968). Ultrastructure of cell walls of genus Mycobacterium. Journal of Ultrastructure Research 25, 46-63.
Kellenberger, E., Ryter, A. \& Sechaud, S. (1958). Electron microscope study of DNA-containing plasms II. Journal of Biophysical and Biochemical Cytology 4, 671-676.

Kollenbrander, P. E. \& Hohman, R. J. (1977). Electron microscopic study of cell surface rings during cell division and morphogenesis of Arthrobacter crystallopoietes. Journal of Bacteriology 130 , 1345-1356.

MARMUR, J. (1961). A procedure for the isolation of deoxyribonucleic acid from micro-organisms. Journal of Molecular Biology 3, 208-218.

Nechaeva, N. B. (1949). Two species of methane oxidizing mycobacteria. Mikrobiologiya 18, 310-317.

PaRK, S. S. \& DeCiccio, B. T. (1974). Autotrophic growth with hydrogen of Mycobacterium gordonae and another scotochromogenic Mycobacterium. International Journal of Systematic Bacteriology 24, 338-345.

PATT, T. E. \& HANSON, R. S. (1978). Intracytoplasmic membrane, phospholipid, and sterol content of 
Methylobacterium organophilum cells grown under different conditions. Journal of Bacteriology 134, 636-644.

Petitprez, A., Roose, P. \& Tacquet, A. (1967). Aspect ultrastructural de Mycobacterium phlei. Journal de Microscopie 6, 229-232.

Schildkraut, C. L., Marmur, J. \& Doty, P. (1962). Determination of the base composition of deoxyribonucleic acid from buoyant density $\mathrm{CsCl}$. Journal of Molecular Biology 4, 430-433.

Seto, N., Sakayanagi, S. \& Iizuka, H. (1975). C compound utilizers isolated from the oil and natural gas fields in Japan. In Proceedings of the International Symposium on Microbial Growth on $C_{1}$-compounds, pp. 35-44. Osaka, Japan: Society of Fermentation Technology, Japan.

Smucker, R. A. \& Pfister, R. M. (1975). Liquid nitrogen cryo-impacting: a new concept for cell disruption. Applied and Environmental Microbiology 30, 445-449.

SPURR, A. R. (1969). A low-viscosity epoxy embedding medium for electron microscopy. Journal of Ultrastructure Research 26, 31-43.
STEERE, R. L. (1957). Electron microscopy of structural detail in frozen biological specimens. Journal of Biophysical and Biochemical Cytology 3, 45-60.

VAN ITERSON, W. (1961). Some features of a remarkable organelle in Bacillus subtilis. Journal of Biophysical and Biochemical Cytology 9, 183-192.

WEAST, R. C. (editor) (1979). In Handbook of Chemistry and Physics, pp. D-233-D-234. Boca Raton, Florida: CRC Press.

WeAVER, T. L. \& Dugan, P. R. (1975). Ultrastructure of Methylosinus trichosporium as revealed by freeze etching. Journal of Bacteriology 121, 704-710.

Wiegel, J. K. W. \& Schlegel, H. G. (1984). Genus Xanthobacter, Wiegel, Wilke, Baumgarten, Opitz and Schlegel 1978, 573. In Bergey's Manual of Systematic Bacteriology, vol. 1, pp. 325-332. Edited by N. R. Krieg. Baltimore: Williams \& Wilkins.

Whittenbury, R., Phillips, K. C. \& Wilkinson, J. F. (1970). Enrichments, isolation, and some properties of methane utilizing bacteria. Journal of General Microbiology 61, 205-218. 